\title{
Supporting University Learning Through Mobile Technologies: A Global Perspective
}

\author{
David Gitumu Mugo (Corresponding author) \\ School of Education \& Social Sciences, Karatina University, P.O. Box 1957-10101, Karatina, Kenya \\ E-mail: davidgm@karatinauniversity.ac.ke \\ Kageni Njagi \\ School of Education, Kabarak University, P.O. Private Bag-20157 Kabarak, Kenya \\ E-mail: kanjagi@kabarakuniversity.ac.ke \\ Bernard Chemwei \\ School of Education, Kabarak University, P.O. Private Bag-20157 Kabarak, Kenya \\ E-mail: bchemwei@yahoo.com \\ Paul Maina Gakuru \\ School of Education, Mt Kenya University, P.O. Box 342-01000 Thika, Kenya \\ E-mail: pmaina2010@gmail.com
}

Received: 14/06/2015

Accepted: 24/07/2015

Published: $31 / 07 / 2015$

doi:10.7575/aiac.ijels.v.3n.3p.42

URL: http://dx.doi.org/10.7575/aiac.ijels.v.3n.3p.42

\begin{abstract}
The workplace in the modern world continues to demand higher qualifications and refined competencies. In the recent past, workers would respond to such demands through learning by correspondence. When the Internet and e-Learning emerged, it received widespread accolade as a solution to the challenges experienced by distant learners. The technology was also seen as an opportunity for educational institutions to leverage their technological uptake to benefit regular students. However, desktop computers and Internet connectivity, which were the drivers of e-learning technologies, were expensive, bulky and scarce. So when mobile technologies emerged, educationist saw an opportunity for addressing the limitations associated with correspondence, "e" and tethered learning. Mobile devices being cheap, portable and reliable received widespread acceptance and possession. So, educators, hardware designers and program developers started to design hardware and applications that would infuse learning content into the devices. The purpose of this review is to demonstrate the potential of mobile technologies in the education market place, highlighting global initiatives and trends. The paper will also review how universities around the world, Africa and in Kenya have oriented themselves for learning with mobile technologies. The study was a documentary analysis of virtual documents stored electronically for access through the Internet, text books, archival repositories and encyclopedias. The study observed a significant high global mobile ownership and usage rates, but was able to demonstrate that despite its pedagogical advantages, the use of the technology for learning purposes at university level is still at the infantry.
\end{abstract}

Keywords: Mobile, Technologies, Universities, adoption, ICT, eLearning

\section{Introduction}

In recent years, individuals and institutions have adopted Information Communication Technologies (ICT) in their operations. Finance, transport, communication, engineering, education, health and agricultural sectors have accepted that ICT can leverage the tasks they do. The technologies are empowering people and institutions, allowing them to radically transform their processes and practices, enabling them perform their functions in a more improved way (Kandiri, 2014:2).

A notable trend in the world of ICT is that consumers are orienting their preferences from fixed technologies towards technologies that are mobile. This trend is motivated by the affordances for convenience on one hand and flexibility on the other. In responding to market demands, individuals and service providers are working closely with manufacturers so that they design hardware and applications that address the mobile nature of individuals (Mberia, Ofafa, Muathe \& Muli (2013:188). This strategy has resulted in an even wider acceptance and adoption of the mobile technologies across the various sectors of human endeavors, including education

In teaching and learning, the convenience and flexibility offered by mobile technologies is freeing teachers and learners from tethered instructional technologies. This by itself has transformed mobile devices from simple communication tools to significant tools for learning and information sharing. The transformation is occurring at a time when learners are getting increasingly equipped with high end mobile phones, tablets and laptops, which allow cheap communication as well as convenient ways of sourcing of learning content (Armatas, Holt and Rice 2005:27). The devices provide wide 
range capabilities and can support flexibility and mobility demanded by the modern student cohort.

The demand for university learning is rising at levels never seen before. In the early 1980s ICT technologies were being introduced in the school system. Scholars speculated that the technology would change the face of education. With well integrated ICT, educators came to appreciate the efficiency with which teachers were performing their duties. Education systems continued to receive support from the government and from the electronic industry to adopt the technology not only for administrative purposes but also for teaching and learning (Tapio, 2005). However despite the will and pressure, the furthest educational institutions went was introducing ICT as a school subject. By the 1990s, the Internet gained widespread popularity, and began to transform culture and civilization in a manner never imagined. When the transfer of bulky data electronically became a reality, universities captured the niche by providing correspondence to distant learners not by post but via electronic mails, popularly known as emails.

From the early 2000, delivery of learning content via electronic mail was improved by the emergence of Virtual Learning Environment. The virtual learning environment was possible through a specialized computer based programs known as Learning Management Systems (LMS). The LMS were designed particularly to benefit college learners experiencing geographical, time or work related constraints. The LMS had the capacity to manage learning scenarios for learners with satisfaction (Solomon, 2013). Through e-learning, individuals began to achieve online academic qualifications while studying distances away from the university campus. However, eLearning had its inherent limitations. It required heavy upfront investment on desktop computers and required Internet bandwidth. Desktop computers were expensive and bulky, and the cost of bandwidth was an ecology of financially endowed institutions and rich individuals. Being heavy and bulky, desktop computers lacked portability and could not afford the flexibility greatly needed by the e-learning student. So when mobile technologies emerged, they appeared as technologies that could solve the challenges inherent in e-learning and other traditional pedagogies. With mobile technologies, educators saw a chance of designing instructional content and pedagogy around the mobile nature of the learner (Sharples, 2007:4).

\section{Mobile Technology and Mobile Learning defined}

There are many definitions of mobile technology. Some schools of thought focus on the definition of the technology itself, while others focus on the learner (Brad, 2013). From a technological definition, mobile technology is any portable technology running on an operating system designed for mobile computing. A mobile device is a small, portable handheld computing device, typically having a display screen with touch input and/or a miniature keyboard, which can incorporate collaborative pedagogy and tailor made resources that can leverage a learning scenario (Clare, 2012). Examples of such devices include laptops, net books, tablets, palmtops, feature phones, smart phones, as well as global positioning system (GPS) devices. These devices have been adopted for mobile learning because they run on modern and powerful telecommunication networks which can support data and Internet access (Hosman and Fife, 2012).

On the other hand mobile learning (also referred as m-learning) is a relatively new field of learning that uses technologies that are mobile, and uses learning spaces that overcome the limitation of time and space (Baharom, 2013:4). M-learning is a form of e-learning that allows learners to access educational resources and material any time anywhere (even when outside traditional learning places) using a mobile technology device. It is perceived that mobile learning mutated from e-learning, owing to the advent of an increasing mobile population, and the perceived limitations of other forms of conventional learning, distance education and e-learning itself (Mehdipour \& and Zerehkafi, 2013).

\subsection{Augmenting a case for mobile technologies for university learning}

Literature on educational technology demonstrates that vibrant research activities seem to revolve around mobile learning. The great interest in the subject demonstrates that educators are appreciating that mobile technologies and mobile learning are emerging as one of the solutions to the challenges faced by education. Various arguments for the technology have been put forward. First, UNESCO (2009) observed that mobile technologies can be an opportunity to leverage existing technological uptake by educational institutions, owing to the cost benefits over computers and over other technologies associated with tethered learning. According to UNESCO, the overall cost for mobile technologies is cheap, reliable and individualized, as opposed to technologies for e-learning which were tethered, scarce, fragile, and a preserve of institutions. Overall, implementation of mobile technology in the university system would be more cost effective than implementing an e-learning program.

The second argument revolves around the advantage that goes with the widespread possession and device acquaintance. The widespread ownership of mobile devices and familiarity that users have with the devices has immeasurable benefits. The cost of connectivity, equipment overlay, as well as expenditure for training faculty and students is considerably reduced, since they already have and know how to use their own mobile devices (UNESCO, 2009). ElHussein (2010)., and Behera (2013) observed that mobile technologies break the barriers of tethered learning, and deliver content by means of a radically new technology that combines the advantages of the Internet, providing convenience and portability of education. Regarding the device familiarity, the time and investment that learning institutions would spend on training users on how to operate the device is significantly reduced.

A third argument is the increasing demand for higher qualifications in the work place: - the demand for higher qualifications in the workplace is pushing the university system to admit a variety of student cohorts into their study programs. Each of the cohorts brings demands that call for a shift in the way instructional technologies are utilized by 
learners and instructors. Armatas, Holt and Rice (2005:33), isolate three unique student cohorts within the modern university: - The first is the school leaver cohort, which resides on campus and receives scheduled instruction mainly through face to face teaching. The second cohort lives a significant distance from the university as non-residents, travelling to campus only when necessary to do so. This group requires sufficient supports so that they can gain full learning experience while they are off campus. The third cohort is a group of learners, engaged in fulltime employment, so have a full work load and heavy study commitment. For this group, the students and their instructors must look for meaningful ways of gaining full education experiences, accessing administrative information and benefiting from university services. The most meaningful method of support is that which would offer flexibility, cost effectiveness and rational time usage. With such a diverse learning community, the authors agree that portable technologies are the most rational option for achieving learner support.

Another augment for mobile technologies is the opportunity that the technology provides in encouraging lifelong learning, even amongst learners in economically disadvantaged populations. Mobile technologies provide learners with increased access to learning opportunities in nontraditional settings (UNESCO, 2009). Mobile technologies are attractive and affordable, providing a great potential for reaching marginalized groups and providing opportunities for learning and development. In situations where access to education is a challenge (due to inaccessible geographical location, conflict or disaster), mobile technologies come in handy to provide that access (Mehdipour \& Zerehkafi, 2013:99).

Various other benefits have been cited by a number of scholars. Crescente and Lee (2011) in Mehdipour and Zerehkafi (2013) observed that mobile technologies are better for learning because they are more lightweight than books and personal computers (PCs), and can be useful tools for students with special needs. Likewise, the excitement with which young adults have accepted the mobile technology can be a cause for improving levels of literacy and participation in education scenarios amongst young adults. Adding to the debate, El-Hussein (2010) and Behera (2013) reiterates that the storage capability of the mobile devices presents great advantages to their users. Internal and external memory of the mobile devices can be used to save data which is then transferred to other users of the device. In this way the learner and their instructors can exchange data, gaining considerable knowledge and experiences. Another notable advantage of mobile learning is that most of m-learning programs are aimed at benefiting older learners, mainly because they have jobs and engagements that make it difficult to attend learning in a traditional setup (UNESCO, 2011:28).

The benefits of m-learning are many, those discussed in this section are sufficient to lay a foundation on which mlearning programs in university learning can be augmented.

\subsection{Adoption of mobile technologies for learning: A Global perspective}

The use of educational technologies is based on the premise that technologies can contribute favorably in achieving universal education in line with the millennium development goals (UNESCO, 2009). It is on this regard that the agency takes a global holistic approach in promoting learning technologies that can be adopted to serve educational goals of access, inclusion, quality, capacity building and knowledge sharing. Interestingly, mobile technologies, if well utilized can achieve all these (UNESCO, 2011). In this section, the researchers will examine the efforts that higher learning institutions across the globe have put to accommodate the technologies for collaborative experiences.

Malaysia, a country with the second largest mobile penetration rates in southeast of Asia has documented evidence as a country that has accepted m-technologies for learning. In Malaysia, 99\% of learners in higher education own a mobile device (Karimuddin, 2008 in Zoraini et al 2009). Consequently, the government of Malaysia, in unison with the communication and multimedia commission has partnered with mobile service providers to encourage the creation of innovative mobile content and applications. The Open University of Malaysia has been a ready consumer of such content (Zoraini, et al 2008). Using the mobile content and applications, the Open University of Malaysia has leveraged on various ICT technologies to reach out to learners who live and work to the interior of Malaysia, where basic infrastructure pose considerable problems. To date the university has produced 14,000 graduates not only from Malaysia but from as far as Bahrain, Yemen, Meldives, Indonesia and Singapore (Zorani et al, 2008).

Japan prides itself as the birth place for mobile web and a hotbed for mobile device innovation. Serkan (2011) confirm that the world's first web application in 1999, as well as the first online billing payment was first developed in Japan. The country also has a popular cyber university and e-colleges with integrated applications for iPhones and iPads. The Cyber University has 24 courses available, with audio and video materials which are sensitively cheap, to the tune of 0.99 US Dollars (Serkan, 2011).

M-learning scenarios in Japan are quite interesting. Being a global leader in the production of electronic gadgets, the country, as expected, has extremely advanced mobile applications, most of which run on third generation (3G) and fourth generation (4G) telecommunication technologies (Kato \& Ricci, 2006). The scholars have been able to demonstrate the m-learning environment in Japan is not driven by the technology itself, rather by some interesting social historical factors. The declining birth rate in Japan, and consequently an ageing population has resulted in vigorous competition for the declining number of young learners. For this reason, learning institutions prefer building a flexible learning environment that through technology can capture the interest and attention of young learners. On the other vein, as social factors in Japan continue to drive people away from the high density metropolis, the result is an uneven distribution of populations. The government falls under pressure to establish non-traditional school system. The 
nontraditional schools are actually the virtual learning centers.

Europe has extremely high mobile usage, affirming itself dominant in high penetration rates of $120 \%$, large numbers of high end smart phones, and increased data usage (UNESCO, 2011). European governments and organizations have funded a number of mobile learning initiatives, though they tended to focus not on the mobile phone itself, but on larger mobile devices like laptops, netbooks, game consoles and tablet devices. Recent initiative by UNESCO has tried to focus more on the mobile phone itself, and how the device can be used to develop teacher competencies across Europe, in countries such as the United Kingdom (UK), France, Finland, Norway, Denmark, Germany, Portugal, Spain and Turkey. The initiative has been very successful in that it has brought researchers together who have provided educators with support and guidance necessary to implement best practices for mobile learning.

The UNESCO initiative was able to isolate European universities as leaders in using mobile technology for disseminating information to students while facilitating communication between teachers, learners and parents. To achieve this, several institutions have developed their own mobile platforms to address specific educational needs. For instance the "Mobilskole platform" has been designed to interact with information management systems of Yorkshire Coast College in the United Kingdom (UK). The platform is able to recognize texts sent via the college's short message service (SMS) number and respond by sending an email to the appropriate staff or department (UNESCO, 2011:27).

The University of Leeds in the UK provides an example of a university that is able to support medical students work and at the same time learn using mobile technologies. The university has an application that offers remote access to educational material such as reference books, medical procedures, study manuals, notes and tests to students while still in their workstation. The application is able to link students to their lecturers and professors via emails and Skype (UNESCO, 2011:28). This confirms the argument by Keegan, et al (2008) who reiterated that Europe and North America have sufficient vibrancy of mobile technologies for learning, much more than that of Japan, South Korean or Malaysia. Developments in mobile technologies in Europe have contributed to greater feasibility of mobile learning and the richness of the courseware that has been and can be developed for mobile learning.

Collaborating the argument of Keegan et al (2008), Nix (2008) states that all the 27 countries of the European Union (EU), spends millions of Euros in the provision of education technologies not only to universities, but also to colleges and schools. The use of High Speed Packet Access (HSPA) broad band technologies has been adopted in the EU with a view of increasing the speed of data transfer, web browsing, audio and video streaming. These technologies have greatly facilitated the development of mobile leaning and have contributed to the richness and complexity of courseware on mobile devices. The projected move in the EU is to shift from the $3 \mathrm{G}$ to $4 \mathrm{G}$ technologies which will not only offer better quality video and sound, but also allow a transfer of larger quantity of information. This means that large quantity of information can be available without the need of a desktop or a laptop computer. Several other European universities have been documented to use mobile technologies for learning. Notable amongst these are Corvinus University of Budapest (Hungary), University of Plovdiv, the Open University of the United Kingdom, the Fern Universität in Hagen Germany, NKI, Bekkestua in Norway and Dirksen Opleidigen from the Netherlands (Keegen, 2006).

Focusing on North America, the United States of America (USA) prides as a country with an array of mobile products and services. By 2009, USA had products worth over six hundred and thirty two (632) million US Dollars and was projected to reach fourteen (14) billion US Dollars by the year 2014 (Fougere, 2010). The USA is thought to be a late adopter of mobile technologies compared to Japan, South Korea, and the United Kindgdom (UK). However in the USA, the use of mobile technologies has found more applications in clinical health care, environment, museums, tourism and consumer education. Limited cases for mobile learning programs in county high schools have been documented in the states of Texas, North Carolina, Virginia, Georgia and Ohio, but regrettably the utilization of mobile technologies for university learning has not taken sufficient root in the USA (Fougere, 2010).

The arguments of Fougere (2010) can be confirmed owing to the scanty literature available on m-learning scenario in the USA. However, the internal medicine department of the University of Michigan has scanty literature that shows some levels of utilization of m-Learning cases. The department, through the University of Michigan Healthcare Systems prides with a portal known as "m-Learning", used predominantly for accessing and tracking learning scenarios amongst teaching faculty and support staff. On the portal, the faculty and staff can access mandatory learning resources, web modules, classes, as well as tracking reports on compulsory requirements. Through the portal, both physicians and nurses, specializing in internal medicine, pediatrics, obstetrics and gynecology, receive physician education at the University's Medical School.

In contrast, literature demonstrates sufficient initiatives for mobile learning in Canada, usually initiated by individual universities and in some instances specific administrative provinces. The province of Ontario for instance has placed legislation for the use of mobile based assistive technology for learners with special needs. Fritschi and Wolf (2012) in Tsinakos (2013:6) provide evidence that other Canadian administrative entities, specifically the province of Alberta and the province of Manitoba have initiated their own programs that catapults Canada as a consumer of mobile technologies in education. Initiatives by individual Canadian universities in the use of mobile platform in the streaming of course material to students have also been documented. Notable among these are the Athabasca University, George Brown College, Durham College, University of Ontario, University of British Columbia, Wilfrid Laurier University, Algonquin College, Ryerson University, OCAD University, and University of Waterloo. Most of the listed universities have 
adopted the "Bring Your Own Device" strategy. In this strategy, students bring their own laptops, tablets or smartphones, while the university provides infrastructure that allow remote delivery of computer applications and learning content to the students' mobile device (Tsinakos, 2013:6).

In this section our perspective will focus on Africa. The African continent is large and expansive, but dotted with numerous educational challenges. The challenges revolve around access to universal education, quality and equity against a backdrop of global competitiveness, regional conflicts and natural disasters (UNESCO, 2011). To address the challenges, UNESCO (2011) and Traxler (2013) concluded that ICT adoption in education can be a favorable intervention. African governments, under their memorandum of understanding and guided by peer review mechanisms of the African Union (OU), initiated ICT interventions at "institutional, provincial, national and regional levels". The interventions focused on the enabling role that ICT can play in improving the quality of teaching and learning while expanding access to learning opportunities. It is out of these initiatives that the e-school initiative by the New Partnership for African Development (NEPAD) was born (Mugo, 2007). School Net Africa by World Link, School Net of Namibia, Smart School Network of Egypt, Gauteng Online, and Khanya Project in South Africa, were also proposed and pretested by individual states. The initiatives were established with a view of mobilizing the fiscal, technical and human capital to support ICT for learning in Africa (UNESCO, 2011). Regrettably none of these projects expanded beyond the pilot phase. They have been overshadowed by the emergence of a more acceptable revolution of mobile technologies.

So as e-learning initiatives were struggling to make an impression to the learning landscape in Africa, other initiatives in the continent were taking shape. Mobile technologies were rising gradually and initiatives such as the One Laptop per Child (OLPC) project in Rwanda, teacher laptop programs in South Africa and Kenya, SMS Education Management Application (SEMA) project in Kenya (2006), MoMaths in South Africa (2007), BridgeIT Project in Tanzania (2007), CyberSmart Project in Senegal, Road to Reading Project in Mali (2009), Distance Learning Center bulk SMS project at the University of Mozambique (2009) and Aga Khan University's (Kenya), mobile support for Certificate in Teacher Education, were indicative that shifts toward mobile learning was taking place (UNESCO, 2012). Commenting on the potential for mobile technologies in Africa, Traxler (2014) sees the continent as a ready market for mobile educational content, higher end specification handset technologies as well as respectable network capacity. In his paper "Potential of Learning with Mobiles in Africa" Traxler (2014:1) argues that the major cause of shift towards mobile adoption in the continent results from the inability of other technologies to leverage learning in a manner that mobile technologies would:

Using mobile devices to deliver learning in Africa will be driven by several factors, a near-universal ownership to (simple) mobile phones and cut throat competition amongst mobile network providers. Most importantly other technology options that might deliver learning are practically non-existent owing to poor infrastructure including unstable mains electricity, poor broadband connectivity, lack of suitable clean secure buildings, lack of technical capacity, lack of software licenses and lack of human capacity. Traxler (2014:1)

Though at an embryonic stage in its development, there is wide acceptance that mobile technologies are emerging more vividly as technologies that can support education provision across the African continent.

We will end this review by focusing on Kenya, a country respected for its unique mobile apps innovations, a country where the mobile phone has made large transformation in the society, replacing wired telephones, credit cards, cash and bank accounts (Roettgers, 2009). Literature reveals that the Aga Khan University has been a pioneer in the use of mobile technologies for learning in Kenya (Winters, 2013), just as it was for the use of computers in schools (Makau, 1988). The need for mobile technologies for learning at the Aga Khan University developed when instructors noted that learning could be supported on mobile devices, more so for student teachers in rural locations or for those students located at greater distances away from the university. The university, noting the widespread usage of cell phones in Kenya, proposed a computer based Modular Object Oriented Dynamic Learning Environment (MOODLE) platform for delivery of content to their distantly isolated student- teachers. However, the university noted that most student-teachers lacked sufficient experience not only with the MOODLE platform but also with computers. The remaining alternative was to design a mobile application program that would provide a learning environment based on SMS, where students and instructors would exchange information regarding course updates, meetings and other enquiries using short texts. Sufficient literature regarding this project is lacking, but UNESCO (2012) appreciates that the course relied on students' mobile phones to support course delivery through the short text services. The course data flow was designed to allow learner collaboration and to achieve peer support.

The African Medical Research Foundation (AMREF) has also made considerable progress in the use of mobile innovations for capacity building (AMREF, 2011). In AMREF, the priority at the time was to design a mobile phone based training activity for nursing as an innovative way to embed current nursing activities to the existing nurse training programs. With the view of this, the Center for Distance Education at the University of London, supported by the London Knowledge Lab (LKL) and the London International Development Center (LIDC), staged a workshop between the 18th and 19th of May 2011 at the AMREF International Training Center, Nairobi, results of which are yet to be published. The conference was staged based on an outcome of a need based analysis, where Kenyan nurses were perceived to be inadequately qualified to treat major diseases such as HIV, Tuberculosis and Malaria. Classroom based 
training for such nurses were proving a considerable challenge to the Nursing Council of Kenya. Therefore, in conjunction with AMREF and support groups, the Nursing Council shifted their emphasis from traditional classroom based teaching and learning, to computer based e-learning and later to mobile learning. Learning with mobile technologies produced encouraging results, and was able to train nurses for higher qualifications. Issues of nurse training were solved without the need of nurses leaving their working stations (AMREF, 2010).

Trends in Kenya's education system indicates that the largest number of students enrolled in Kenyan universities are either nonresidents or working, yet require off campus access to learning resources. A survey on e-readiness in Kenya, conducted by Kenya Education Network (KENET) in 2008, demonstrated that $99 \%$ of university students and faculty have access to a mobile device. The study further revealed that the students and staff possess sophisticated devices with data handling capabilities, which can provide access to online learning resources. So it is believed that the use of mobile devices to access online learning is likely to increase more than before. The study by KENET demonstrates that if Kenyan universities were to mount mobile learning programs, they would mount it on infrastructure that has already been established by mobile services providers and with devices that are already owned by students and their lecturers. The technological investment by the universities would only involve recruiting human capital and purchase of learning management systems that can be supported on mobile devices.

In the most recent past, universities in Kenya have demonstrated positive attempts towards learning with mobile technologies. In June 2014, Kenyatta University initiated a program that provides a free phone tablet for every student enrolling into diploma, undergraduate and post graduate programs under the open and distance learning mode. The program is designed for students who are unable to take up full time on campus learning, allowing them a cost effective means of accessing courseware with flexibility and convenience. Kabarak University in Nakuru, Kenya also has a mobile application popularly referred to as Kabarak University Online (KABUO). The application allows the university community not only to access events updates but also access course learning content on their mobile devices. Literature for the adoption of mobile technologies by other Kenyan universities is scanty.

\section{Conclusions}

The ownership of mobile devices is quite high, and in most regions of the world has exceeded the $100 \%$ mark, thanks to the low cost of the devices. However, the adoption of the devices for learning level is sufficiently low, and can be due to one or all of the following reasons some of which have been described by Tsinakos (2013):

1. Lack of policies and a framework that educators and stakeholders would follow to ensure appropriate use of the devices for learning cases;

2. Adoption of worst practices especially at lower levels of schooling where mobile devices have been banned from students within the school environment. However, this practice is not a concern at university level;

3. Hesitating mind amongst parents and school managers who fear that students will be exposed to inappropriate material (specifically pornography), cyber bulling, or cheating at examinations;

4. Limited resources of fully functional and of high quality educational content for mobile devices are an additional barrier to mobile learning. This is further expanded by the lack of specific technical programs to train educators and trainers in the field of mobile content development; and

5. Lack of standards dues to a variety of device brands, screen sizes and operating systems.

\section{References}

Armatas, C., \& Holt, D. \& Rice (2005). Balancing the possibilities for mobile technologies in higher education. Telstra Research Laboratories; Clayton, 770 Blackburn Road, Clayton, 3168. Australia.

Baharom, S.S. (2013). Designing Mobile Learning Activities in Malaysian Higher Education Context: Asocial Constructivist Approach. An unpublished Ph.D. thesis Salford Business School, University of Salford, Salford, UK.

Behera, S.K. (2013) M-learning: a new learning paradigm. International Journal on New Trends in Education and their Implications. April 2013 Volume 4 Issue, 2 Article 03. Downloaded on $16^{\text {th }}$ June 14 from http://www.ijonte.org

Bland, H (2013). Mobile Technology definition. Ohio State University. Retrieved on $11^{\text {th }}$ August 2015 from http://www.slideshare.net/BradH2/mobile-learning-definitions?related=3

El-Hussein, M. O. M., \& Cronje, J.C. (2010). Defining Mobile Learning in the Higher Education Landscape. In Educational Technology \& Society, 13(3), 12-21.

Fougere, N. (2010). US leads the Market for mobile product learning. Retrieved on $22^{\text {nd }}$ June 2014 from: http://www.litmos.com/mobile-learning/us-leads-the-global-mobile-learning-market-mlearning

Hosman, L., Fife, E. (2012). The Use of Mobile Phones for Development in Africa: Top-Down-Meets-Bottom-Up Partnering. Journal of community informatics, 8(2).

IPSOS (2014) KU takes learning to new level with digital school. Business Daily Date: 03.07.2014 Page 17. Downloaded on $24^{\text {th }}$ July 2015 from http://www.ipsos.co.ke.pdfon 
Issham, I., Azizan, S.N., Azman, N. (2011). Accessing innovativeness of distance learners towards their readiness in embracing technology. African Journal of Business management Volume 5(33), Downloaded on 13.11 .14 from www.academicjournals.org/AJBM

Kandiri, J.M. (2014). Effective Implementation of Technology Innovations in Higher Education Institutions: A Survey of Selected Projects in African Universities. An unpublished PHD thesis submitted to the School of Business Kenyatta University.

Kato, M.K., Ricci, V.C. (2006). The eLearning Guild's Learning Solutions: Practical Applications of Technology for Learning. The e-learning Guild Publication.

Keegan, D et al (2008) The Impact of new technologies on distance learning students. Retrieved on $6^{\text {th }}$ August 2015 from http://deposit.fernuni-hagen.de/1561/1/Research Report_3_2008.pdf

Makau, B.M. (1988). Computer in Kenyan Schools; a case study of an innovation in Kenya. Canada: IDRC.

Mberia, P.M., Ofafa G.A., Muathe, M.A., Muli, J. (2013). An empirical investigation on the relationship between technological infrastructure and government regulations on Effective operations of m-payment systems in Kenya. International Journal of Arts and Commerce ISSN 1929-7106. Downloaded on 12 $2^{\text {th }}$ January 2015 from www.ijac.org.uk

Mehdipour, Y., Zerehkafi, H. (2013). Mobile learning; benefits and challenges. International Journal of Computational Engineering Research, Vol 3, Issue 6.

Mugo, D.G. (2007). Integrating emerging ICT technologies in science instruction. The successes and challenges facing NEPAD e-School project, a case study of Mumbi Girls' secondary school, Murang'a, Kenya. Unpublished Master of Education Project, Nairobi: Kenyatta University.

Muhanna, W.N., \& Sha'r, A. (2009). University Students' Attitudes towards Cell Phone Learning Environment. International Journal of Interactive Mobile Technologies. Downloaded 15 $5^{\text {th }}$ November 2014 from http://onlinejournals.org/index.php/i-jim/issue/view/67

Pollara, P. (2011). Mobile Learning in Higher Education: A Glimpse and a comparison of student and faculty readiness, attitudes and perceptions: An unpublished dissertation submitted to the Graduate Faculty of the Louisiana State University and Agricultural \& Mechanical College.

Roettgers, J. (2009). Kenya's mobile banking revolution. Retrieved on 15 ${ }^{\text {th }}$ August 2015 from http://gigaom.com Kenya's-mobile-banking-revolution/

Serkan, T. (2011). Mobile Learning in Japan. Downloaded on $27^{\text {th }}$ February 2012 from www.slideshare.net

Sharples, M. (2007). A short history of mobile learning and issues to consider. Learning Science Research Institute, University of Nottingham. Retrieved on $11^{\text {th }}$ August 2015 from http://www.slideshare net/ sharp lem /history-of-mobilelearning-mlearn-2007-doctoral-consortium-Oct-2007

Solomon, A.D. (2013). A critical understanding of Learning Management System, downloaded on $8^{\text {th }}$ August 2015 from http://www.academia.edu

Tapio V. (2005). The future of eLearning. A Short History of eLearning and a Look into the Future of Computer Mediated Learning. Swedish School of Social Science University of Helsinki.

Traxler. J. (2014). Potential of Learning with Mobiles in Africa. Wise Education Review. Retrieved on 3-9-14 from http://www.wise-qatar.org /john-traxler-mobile-learning-africa

Tsinakos, A. (2013). Global Mobile learning implementation Trends. Beijing: China Central Radio \& TV University Press.

UNESCO, (2011). From text books to telephone, downloaded on $18^{\text {th }}$ May 2015 www.UNESCO.org

UNESCO, (2011). Mobile Learning Week Report on New learning cultures, opportunities and challenges of the digital world. Downloaded on $7^{\text {th }}$ September 2014 from www.UNESCO.org

UNESCO, (2012). Turning on Mobile Learning, Illustrative Initiatives Downloaded on $7^{\text {th }}$ September 2014 from www.UNESCO.org

UNESCO, (2012). Mobile Learning for Teachers Exploring the Potential of Mobile Technologies to Support Teachers and Improve Practice. Downloaded on 7-9-14 from www.UNESCO.org

Winters, N. (2013). Re-positioning the teacher as central to mobile learning for development. London Knowledge Lab, Institute of Education, University of London.

Zoraini, W.A. et al (2008). Research methods and design in human development. Unpublished lecture notes on Human Growth and development.

Zoraini, W.A. ET al (2009). A study on learner readiness for mobile learning at Open University of Malaysia. Proceedings of IADIS International Conference on Mobile Learning 2009. 